(C) 2018

Тищенко В. М., доктор сільськогосподарських наук, професор,

Гусенкова О. В., здобувач,

Шандиба В. В., здобувач

Полтавська державна аграрна академія

\title{
РІВЕНЬ ФОРМУВАННЯ, МІНЛИВІСТЬ ТА ГЕНЕТИЧНІ ЗВ'ЯЗКИ КІЛЬКІСНИХ ОЗНАК СОРТІВ ТА СЕЛЕКЦІЙНИХ ЛІНІЙ ПШЕНИЦІ ОЗИМОЇ
}

\author{
Рецензент - доктор сільськогосподарських наук, професор П. В. Писаренко
}

В статті викладені результати експерименту по вивченню рівня формування та мінливості ознаки «маса зерна з колосу» (M1) сортів та селекційних ліній (СЛ) пшениці озимої та ї̈ генетичні кореляції 3 кількісними ознаками в залежності від року вирощування та строків сівби. В досліді використовували 3 строки сівби: ранній (1вересня, СП-1), оптимальний (15 вересня, СП-2), пізній (1 жовтня, СП-3). В задачу експерименту входило дослідити як формується маса зерна з колосу за строками сівби та за роками досліджень, а також визначити як формуються генетичні зв'язки оптимального строку сівби по відношенню до раннього $i$ пізнього $і$ коли більш виразно проявляються генетичні корелячії між кількісним ознаками. В процесі дослідження встановлено, щуо найвищий рівень ознаки «маса зерна з колоса» формувався в 2015 рочі. Визначено, щуо ознака «маса зерна з колоса» має пряму кореляційну залежність із такими структурними елементами як кількість зерен з колоса, маса колоса з насінням та маса рослини, і мени стійкі генетичні зв'язки з іншими кількісними ознаками як за роками досліджень, так $і$ за строками сівби. Досліджено, що генетичні зв'язки оптимального строку сівби ознаки «маса зерна з колоса» з генеративними $i$ вегетативними ознаками мають наближене значення до СП-1 та СП-3 і формуються з незначною різницею.

Ключові слова: пшениия озима, ознака, строки сівби, генетичні кореляиії.

Постановка проблеми. В попередніх дослідженнях в Полтавській аграрній академії (20012012 рр.) багато уваги приділялося вивченню генетичних кореляцій $(\mathrm{rg})$ кількісних ознак у сортів та селекційних ліній в спеціальному досліді за строками сівби (СП-1 - ранній 1 вересня; СП-3 - пізній 1 жовтня) і в аналіз генетичних кореляцій залучалися визначені структурним аналізом кількісні ознаки двох строків сівби різницею в один місяць. Безумовно, в результатах експерименту не був задіяний оптимальний строк сівби. Тому нами, починаючи з 2013 року, в дослід за строками сівби був включений ще один варіант - оптимальний строк сівби (СП-2 15 вересня).
Аналіз основних досліджень і публікацій, в яких започатковано розв'язання проблеми. Урожайність пшениці формується під впливом складного комплексу умов середовища, кожна 3 яких впливає на їі кількість і якість. У цьому зв'язку аналіз окремих елементів урожайності дозволяє повніше виявити взаємовідношення між рослинами пшениці і середовищем в різні періоди вегетації [4]. Продуктивність рослин обумовлюється різноманітним поєднанням кількісних ознак, які в свою чергу $є$ результатом складної взаємодії генотипу та умов зовнішнього середовища [1]. На думку В. В. Лихочвора, набагато ширші можливості росту врожайності закладені у показнику маси зерна 3 колоса. Адже саме добуток кількості продуктивних стебел та маси зерна з одного колоса, визначені перед збиранням, дають нам величину біологічного врожаю [9, 2].

При відборі з гібридних популяцій цінних рекомбінантних генотипів особлива увага приділяється продуктивності колоса, який є визначальним компонентом врожаю $[7,3,5]$. Для створення моделі сорту і підвищення ефективності селекційної роботи необхідно враховувати особливості кореляційних зв'язків між продуктивністю колоса і елементами, які впливають на іiі формування [7, 8]. Разом із тим, у різних екологічних умовах характер цих зв'язків має свої особливості, обумовлені генотип-середовищною взаємодією при реалізації генотипу в онтогенезі $[7,6]$.

Мета досліджень. Метою експерименту було дослідити чи різняться генетичні зв'язки оптимального строку сівби по відношенню до раннього і пізнього строків і коли більш виразно проявляються генетичні кореляції між головними складовими врожайності. Крім того необхідно було дослідити рівень формування і мінливість ознаки «маса зерна з колосу» як за роками досліджень, так і за строками сівби.

Завданням досліджень було проведення статистичного та кореляційного аналізів кількісних ознак пшениці озимої. 


\section{СІЛЬСЬКЕ ГОСПОДАРСТВО. РОСЛИННИЦТВО}

Матеріали і методи досліджень. Матеріалом дослідження були сорти та селекційні лінії озимої пшениці, які вирощувались на селекційних ділянках впродовж 2013-2016 років. По досліджуваних сортах та селекційних лініях (СЛ) проводився структурний аналіз по 25 рослинах, які вирізали на дослідних ділянках, доводили до повітряно-сухого стану та проводили по кожній рослині вимірювання, підрахунки, зважування. 3 великого різноманіття кількісних ознак в аналіз залучали ознаку генеративної частини рослини «маса зерна з колоса».

У процесі аналізу експериментальних даних використовувався метод групування по ознаці «маса зерна з колоса» (M1), будувався варіаційний ряд і в аналіз залучали мінімальне та максимальне значення ознаки М1. Крім того, по М1 проводили обчислення по середнім арифметичним значенням $(\bar{x})$ та лімітами варіювання (LV). Статистичні показники та їх похибки обчислювали на ПК. По середнім арифметичним проводили кореляційний аналіз.

Результати досліджень. Досліди проводилися впродовж 2013-2016 років і в аналіз залучалися такі ознаки як маса зерна 3 колоса (M1); кількість зерен $з$ колоса (КЗ); маса колоса 3 насінням (М3); кількість колосків в колосі (КК); маса тисячі зерен (МТ3); товщина соломини другого міжвузля (ТС2M); довжина колоса (ДК); маса рослини (М2); маса стебла (М5); маса полови (M4).

Генетичні кореляції ознаки M1 (маса зерна 3 колоса) визначені на великій вибірці сортів та селекційних ліній пшениці озимої в експерименті за роки досліджень і за строками сівби. Були залучені середні значення кількісних ознак по 25 рослинах, по кожному сорту. Всього було задіяні 1156 сортів і селекційних ліній і на цій вибірці проведений статистичний і кореляційний аналізи.

Що стосується параметрів формування ознаки M1 і іiі мінливості (табл. 1), то рівень ії був від $(1,93 \pm 0,03-2013$ р. СП-3) до (3,21 $\pm 0,04-2015$ p. СП-1). Слід відмітити, що формування ознаки було вищим (за всіма роками досліджень) у першому строкові сівби. Відмічена також різниця рівня формування маси зерна 3 колосу за роками досліджень. Так, у 2015 році за трьома строками сівби ознака була на рівні $3,21 \pm 0,04$ (СП-1); 3,16 $\pm 0,04$ (СП-2) і 3,06 $\pm 0,04$ (СП-1), що на 1,17-1,28 вище, ніж у інші роки.

Викликають зацікавленість окремі генотипи озимої пшениці, які формували ознаку за лімітами варіювання, на рівні 4,07 і 4,35 г - (СП-1 (Еритроспермум 912/86×Альбатрос одеський) $\times$ Станічна - 4,02 г, с. Говтва - 4,07 г, (Перемога $2 \times$ Коломак 3)×Зерноград $11-4,30$ г, Донецька $88 \times$ Пемога $2-4,35$ г) та в СП-2 (Перемога

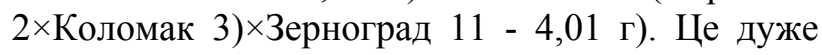
високий показник маси зерна 3 колоса і такі сорти і СЛ можуть бути залучені в процес гібридизації як вихідний матеріал.

Рівень генетичної варіації у досліді за роками досліджень і строками сівби по М1 формувався від 11,7 \% (СП-2; 2014 р.) до 19,5 (СП-1; 2013р.) (табл. 2).

За роками досліджень генетичні кореляції між М1× К3 були стабільно високими, крім 2014 року, де за пізнього строку сівби генетичні зв'язки зменшувалися до середніх значень $(\mathrm{rg}=0,56)$. За оптимального строку сівби генетичні кореляції між М1× К3 мали середнє значення між СП-1 та СП-3, тобто дещо знижувались в порівнянні 3 СП-1 та СП-3.

\section{1. Формування і мінливість ознаки «маса зерна з колоса» сортів та селекційних ліній пшениці озимої в залежності від року вирощування та строків сівби}

\begin{tabular}{|c|c|c|c|c|c|}
\hline \multirow{2}{*}{ Рік } & \multirow{2}{*}{ Строки сівби } & \multirow{2}{*}{$\begin{array}{c}\text { Кількість сортів } \\
\text { та СЛ }\end{array}$} & \multicolumn{3}{|c|}{ Статистичні показники } \\
\hline & & & $\bar{x}$ & LV & $\mathrm{CV} \%$ \\
\hline \multirow{3}{*}{$\frac{m}{\stackrel{i}{~}}$} & СП-1 & 106 & $2,04 \pm 0,04$ & $0,87-3,10$ & 19,46 \\
\hline & СП-2 & 100 & $2,07 \pm 0,04$ & $1,23-2,92$ & 16,89 \\
\hline & СП-3 & 107 & $1,93 \pm 0,03$ & $1,16-2,83$ & 16,27 \\
\hline \multirow{3}{*}{$\stackrel{\nabla}{\stackrel{i}{~}}$} & СП-1 & 66 & $2,29 \pm 0,03$ & $1,69-2,87$ & 11,96 \\
\hline & СП-2 & 90 & $2,14 \pm 0,03$ & $1,33-2,77$ & 13,13 \\
\hline & CП-3 & 89 & $2,04 \pm 0,02$ & $1,51-2,58$ & 11,68 \\
\hline \multirow{3}{*}{$\frac{n}{\stackrel{n}{i}}$} & CП-1 & 111 & $3,21 \pm 0,04$ & $1,96-4,35$ & 14,64 \\
\hline & СП-2 & 112 & $3,16 \pm 0,04$ & $2,05-4,07$ & 13,90 \\
\hline & CП-3 & 110 & $3,06 \pm 0,04$ & $1,96-3,97$ & 12,47 \\
\hline \multirow{3}{*}{$\stackrel{\circ}{\stackrel{0}{i}}$} & CП-1 & 87 & $2,15 \pm 0,04$ & $1,53-3,08$ & 16,10 \\
\hline & СП-2 & 89 & $2,13 \pm 0,03$ & $1,26-3,02$ & 14,76 \\
\hline & СП-3 & 89 & $2,09 \pm 0,03$ & $1,33-2,81$ & 15,30 \\
\hline
\end{tabular}


СІЛЬСЬКЕ ГОСПОДАРСТВО. РОСЛИННИЦТВО

\section{2. Генетичні кореляції (rg) ознаки маса зерна з колоса (M1) з кількісними ознаками сортів} та селекційних ліній пшениці озимої в залежності від року вирощування та строків сівби

\begin{tabular}{|c|c|c|c|c|c|c|c|c|c|c|}
\hline Рік & $\begin{array}{c}\text { Строки } \\
\text { сівби }\end{array}$ & К3 & M3 & КK & MT3 & $\begin{array}{l}\text { TC- } \\
2 \mathrm{M} \\
\end{array}$ & ДК & M2 & M5 & M4 \\
\hline \multirow{3}{*}{$\stackrel{m}{\stackrel{n}{\sim}}$} & СП-1 & 0,92 & 0,96 & 0,64 & 0,71 & 0,33 & 0,54 & 0,92 & 0,67 & 0,45 \\
\hline & СП-2 & 0,91 & 0,95 & 0,60 & 0,72 & 0,30 & 0,49 & 0,95 & 0,60 & 0,48 \\
\hline & СП-3 & 0,93 & 0,95 & 0,63 & 0,66 & $\mathbf{0 , 1 8}$ & 0,37 & 0,95 & 0,49 & 0,66 \\
\hline \multirow{3}{*}{ 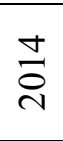 } & СП-1 & 0,75 & 0,93 & 0,52 & 0,52 & 0,52 & 0,32 & 0,83 & 0,35 & 0,48 \\
\hline & СП-2 & 0,81 & 0,94 & 0,51 & 0,76 & 0,61 & 0,44 & 0,80 & 0,36 & 0,42 \\
\hline & СП-3 & 0,56 & 0,94 & 0,40 & 0,27 & 0,48 & 0,44 & 0,84 & 0,48 & 0,38 \\
\hline \multirow{3}{*}{$\frac{n}{\stackrel{n}{d}}$} & СП-1 & 0,87 & 0,98 & 0,77 & 0,60 & 0,72 & 0,56 & 0,96 & 0,82 & 0,84 \\
\hline & СП-2 & 0,86 & 0,99 & 0,71 & 0,65 & 0,25 & 0,67 & 0,97 & 0,83 & 0,87 \\
\hline & СП-3 & 0,84 & 0,98 & 0,59 & 0,72 & 0,62 & 0,59 & 0,95 & 0,76 & 0,81 \\
\hline \multirow{3}{*}{$\stackrel{\circ}{\stackrel{0}{*}}$} & СП-1 & 0,76 & 0,98 & 0,70 & 0,68 & 0,55 & 0,57 & 0,97 & 0,81 & 0,79 \\
\hline & СП-2 & 0,63 & 0,98 & 0,58 & 0,74 & 0,53 & 0,47 & 0,96 & 0,79 & 0,70 \\
\hline & СП-3 & 0,67 & 0,98 & 0,61 & 0,70 & 0,49 & 0,47 & 0,96 & 0,77 & 0,75 \\
\hline
\end{tabular}

Генетичні зв'язки між М1× М3 були стабільно високими як за роками, так і за строками сівби $(\mathrm{rg}=0,93-0,98)$.

Слід зазначити, що високий кореляційний зв'язок ознака M1 мала з К3, М3 та М2, а з іншими кількісними ознаками генетичні зв'язки зменшувались як за роками досліджень, так і за строками сівби.

Генетичні зв'язки між М1×КК в 2014-2016 роках мали середнє значення або трішки більше середнього, а в СП-3 2014 та 2015 років зменшувались відповідно від $(\mathrm{rg}=0,59 ; 2015)$ до $(\mathrm{rg}=0,40 ; 2014)$. В оптимальному строкові сівби (СП-2) кореляційні зв'язки мали майже таке ж саме значення, як і в СП-1, лише в 2016 році вони були меншими $(\mathrm{rg}=0,58)$.

Між М1×МТЗ генетичні зв'язки мали середнє значення як за строками сівби, так і за роками досліджень, лише в 2014 році в СП-3 генетичні зв'язки зменшувалися від $(\mathrm{rg}=0,27)$ до $(\mathrm{rg}=0,52)$. Слід відмітити, що $\mathrm{rg}$ між М1×МТЗмали зовсім протилежний характер по відношенню до КЗхМТЗ.

Генетичні кореляції ознаки М1 з ТС-2М, ДК, M5, M4 носили різний характер, але генетичні

\section{БІБЛІОГРАФІЯ}

1. Ковтун В. И., Ковтун Л. Н. Озернённость, масса зерна колоса и масса 1000 зёрен в повышении урожайности озимой мягкой пшеницы // Известия Оренбургского государственного аграрного университета. - Оренбург, 2015. - №3 (53). - C. 27-29.

2. Лихочвор В. Продуктивність колоса озимої пшениці [Електронний ресурс] / В. Лихочвор, С. Костючко // Агробізнес. - 2010. - №14-16. Режим доступу: http://www.agro- зв'язки оптимального строку сівби мали середнє значення між СП-1 та СП-3.

Таким чином, при дослідженні генетичних зв'язків ознаки «маса зерна 3 колоса» $з$ генеративними і вегетативними ознаками встановлено, що за оптимального строку сівби рівень генетичних кореляцій формувався майже такий, як за раннього і пізнього строків сівби з невеликою різницею як за роками, так і за строками сівби.

Висновки. В процесі дослідження встановлено, що найвищий рівень ознаки «маса зерна 3 колоса» формувався в 2015 році. Визначено, що ознака «маса зерна 3 колоса» має пряму кореляційну залежність із такими структурними елементами як К3, М3 та М2 і менш стійкі генетичні зв'язки 3 іншими кількісними ознаками. Досліджено, що генетичні зв'язки оптимального строку сівби ознаки «маса зерна 3 колоса» 3 генеративними i вегетативними ознаками мають наближене значення до СП-1 та СП-3 і формуються з незначною різницею.

Сорти та селекційні лінії, які мають масу зерна 3 колоса 4,0 г і більше, рекомендуємо залучати в процес гібридизації.

business.com.ua/2010-06-11-12-53-00/542-201107-07-09-36-03.html.

3. Лукьяненко П. П. Методы и результаты селекции озимой пшеницы: Избранные труды. М. : Колос, 1973. - С. 254-287.

4. Малюга Н. Г. Влияние технологи возделывания на продуктивность озимой пшеницы. [Електронний ресурс] / Н. Г. Малюга, Т. В. Логойда, А. В. Курепин // Научный журнал КубГАУ. - 2014. - №99(05). Режим доступу: 
http://ej.kubagro.ru/2014/05/pdf/55.pdf

5. Натрова 3., Смочек Я. Продуктивность колоса зерновых культур. - М. : Колос, 1983. - 45 с.

6. Нурбеков С. И. Биологические критерии селекции озимой мягкой пшеницы сухостепного агроэкотипа: Автореф. дисс. доктора биол. наук. - Республика Казахстан, Алмалыбак, 2010. C. 24.

7. Олейник A. А. Адаптивный характер корреляционных зависимостей определяющих продуктивность главного колоса у сортов и гибридов озимой мягкой пшеницы на черноземе выщелоченном центрального Предкавказья [Електронний ресурс] / А. А. Олейник, А. А. Кривенко и др. // Научный журнал КубГАУ. - 2014. №99(05). Режим доступу: http://ej.kubagro.ru/ 2014/05/pdf/67.pdf

8. Панфилова О. С. Исходный материал для селекции яровой мягкой пшеницы на продуктивность в условиях центрального Нечерноземья: Автореф. дисс. канд. с.-х.наук. - Москва, 2010. C. 18 .

9. Рожков А. О. Формування продуктивності колоса рослин пшениці озимої залежно від строку сівби та норми висіву / А. О. Рожков, М. А. Бобро, Т. В. Рижик // Вісник Полтавської державної аграрної академії. - Полтава, 2016. № 1-2. - C. 6-11. 